\title{
PERBEDAAN HASIL BELAJAR ANTARA MAHASISWA YANG BERASAL DARI SMA DENGAN SMK PADA PROGRAM STUDI PENDIDIKAN AKUNTANSI UNIVERSITAS PGRI PALEMBANG
}

\author{
Oleh: Herlisa Putra \\ (SMK BINA SRIWIJAYA PALEMBANG)
}

\begin{abstract}
Abstrak-Program Studi Pendidikan Akuntansi merupakan suatu program dari ilmu sosial yang mahasiswanya memiliki latar belakang pendidikan yang berbeda-beda yaitu dari SMA Jurusan IPS dan IPA dengan SMK Jurusan Akuntansi dan Administrasi Perkantoran. Metode yang digunakan dalam penelitian ini adalah metode komparatif (membandingkan). Berdasarkan hasil pembahasan, di dapat bahwa rata-rata nilai Pengantar Akuntansi mahasiswa yang berasal dari SMA Jurusan IPA 77,16, Jurusan IPS 80,595, dan Mahasiswa yang berasal dari SMK 86,429 dari hasil rata-rata ini maka di dapat rata-rata tertinggi adalah mahasiswa yang berasal dari SMK Jurusan Akuntansi dengan SMA jurusan IPS. Hasil pengujian hipotesis dengan menggunakan statistik parametris uji komparatif lebih dari dua sampel independen, diperoleh hasil $F_{\text {hitung }} 6,152>F_{\text {tabel }}$ 0,05/2 = 3,11 maka $H_{a}$ diterima dan $H_{o}$ ditolak. Berarti terdapat perbedaan yang sangat signifikan antara hasil belajar mahasiswa yang berasal dari SMA dengan SMK pada Program Studi Pendidikan Akuntansi Universitas PGRI Palembang.
\end{abstract}

Kata Kunci: Perbedaan Hasil Belajar, Mahsiswa dari SMA, Mahsiswa dari SMK

\begin{abstract}
The Accounting Education Study Program is a program of social science where students have different educational backgrounds, namely from the Social Sciences and Social Sciences Department High School with the Vocational School of Accounting and Office Administration. The method used in this study is the comparative method (comparing). Based on the results of the discussion, it can be found that the average value of Introduction to Accounting students who come from the Natural Sciences Department 77.16, Social Sciences 80.595, and Students who come from Vocational Schools 86.442 from these average results, the highest average is students who came from a vocational majoring in accounting with a high school majoring in social studies. The results of testing the hypothesis by using the parametric statistical comparative test of more than two independent samples, the results obtained Fcount 6.152> Ftable $0.05 / 2=3.11$ then Ha is accepted and Ho rejected. Means there is a very significant difference between student learning outcomes from high school and vocational high school in the Accounting Education Study Program at PGRI University Palembang.
\end{abstract}

Keywords: Differences in Learning Outcomes, Students from High Schools, Students from Vocational Schools. 


\section{PENDAHULUAN}

Berbicara tentang pendidikan tidak lepas dari berbicara tentang hasil belajar atau prestasi peserta didik. Sudjana (2009:22) "Hasil Belajar adalah kemampuan yang dimiliki siswa setelah menerima pengalaman belajar". Untuk memperoleh hasil belajar yang baik tentu tidak dapat diraih begitu saja,memerlukan suatu kegiatan proses belajar mengajar. Pencapaian hasil belajar padadasarnya menjadi sesuatu yang sangat penting pada saat mengawali pendidikan formal di jenjangperguruan tinggi. Hasil belajar yang dicapai pada jenjang SMK dan SMA, akan menjadi landasan yang kuat untukmenentukan keberhasilan mencapai atau memperoleh hasil belajar pada mata kuliah yang sesuai dengan mata pelajaran di SMK dan SMA.

Salah satu faktor yang cukup menentukan keberhasilan seorang mahasiswa di bangku kuliah adalah latar belakang asal sekolah. Latar belakang pendidikan seorang mahasiswa cocok dengan jurusan yang dipilihnya di perguruan tinggi biasanya akan memberikan kondisi atau dampak yang baik bagi mahasiswa tersebut karena ia memiliki pengetahuan dasar yang lebih banyak tentang ilmu yang dipilihnya.

Program studi pendidikan akuntansi merupakan suatu program dari ilmu sosial yang mahasiswanya memiliki latar belakang yang berbeda-beda yaitu:

a. SMK Jurusan Bisnis dan Manajemen terdiri dari Akuntansi dan Administrasi perkantoran. Jurusan Teknologi dan Rekayasa, yang terdiri dari teknik bangunan, teknik ketenagalistrikan, teknik mesin dan teknik otomotif.Jurusan Teknologi Informasi dan Komunikasi, terdiri dari teknik telekomunikasi, teknik komputer dan informatika. JurusanKesehatan terdiri dari kesehatan dan perawatan sosial. JurusanSeni, Kerajinan dan Pariwisata terdiri dari seni rupa, desain dan produksi kria, seni pertunjukan, parawisata, tata boga, tata kecantikan dan tata busana. Jurusan Agribisnis dan Agroindustri terdiri dari agribisnis produksi tanaman, ternak dan sumber daya perairan.

b. SMA Jurusan IPS, IPA, dan Ilmu Pengetahuan Bahasa.

c. MA Jurusan IPS dan IPA

Dari latar belakang ini hasil belajar mahasiswa akan bervariasi karena latar pendidikan menengah mereka berbeda-beda.Berdasarkan informasi yang didapat dari Disdikporaperbedaan siswa dalam menerima pelajaran akuntansi di sekolah sebagai berikut:

Pertama,mahasiswa yang berasal dari SMK ataupun yang dahulu disebut Sekolah Menengah Ekonomi AtasJurusan Akuntansi mendapat pembelajaran tentang 
akuntansi sebanyak 39015 menit atau 650 jam pelajaran yang disajikan selama 3 tahun berturut-turut. Mata pelajaran akuntansi telahmenjadi mata pelajaran wajib untuk siswa/i mulai dari semester awal sekolah sampai semester akhir kelas tiga dengan rata-rata duamata pelajaran akuntansi setiap semester.

Kedua, mahasiswa yang berasal dari SMK Jurusan Administrasi Perkantoran mendapat pembelajaran tentangakuntansi sebanyak 56 jam dari jumlah total mata pelajaran yang disajikan selama 3 semester. Mata pelajaran akuntansi yang didapat dimulai dari semester awal dan hingga sampai semester 3.Ketiga, mahasiswa yang berasal dari SMA Jurusan Ilmu PengetahuanSosial mendapat pembelajaran tentangakuntansi sebanyak 116 jam pelajaran dari jumlah total mata pelajaran yang disajikan selama 1tahunajaran. Mata pelajaran akuntansi yang didapat dimulai dari semester 5 dan 6 .

Keempat, mahasiswa yang berasal dari SMAJurusan Ilmu Pengetahuan Alammendapatkan pelajaran ekonomi sebanyak 62 jam dari jumlah total mata pelajaran yang disajikan selama 4 semester.Kelima, mahasiswa yang berasal dari SMA Jurusan IPB dan dari SMK Jurusan Teknologi dan Rekayasa, Teknologi Informasi dan Komunikasi, Kesehatan, Seni, Kerajinan dan Pariwisata, dan Agribisnis Produksi Tanaman tidak sama sekali menerima pelajaran akuntansi. Keenam, mahasiswa yang berasal dari Madrasah Aliyah Jurusan Sosial mendapatkan mata pelajaran akuntansi sebanyak 116 jam pelajaran dari jumlah total mata pelajaran yang disajikan selama 1tahunajaran. Mata pelajaran akuntansi yang didapat dimulai dari semester 5 dan 6

Prodi Pendidikan Akuntansi FKIP Universitas PGRI Palembang dalam menerima mahasiswa baru yang berasal dari SMK Jurusan Akuntansi dan Administrasi Perkantoran dan dari SMA Jurusan IPS dan IPA serta, dari MA Jurusan IPS tidak dibedakan semuanya memiliki kesempatan bergabung di Prodi Pendidikan Akuntansi tanpa ada syarat khusus yang membedakan dari latar belakang sekolah serta di perkuliahan tidak ada pembeda semuanya sama mengikuti semua mata kuliah yang ditentukan oleh Prodi Pendidikan Akuntansi. Jadi disini mahasiswa nya sama dalam menerima pelajaran tanpa ada perbedaan.

Berdasarkan Informasi yang peneliti peroleh dari beberapa mahasiswa angkatan 2014 dan 2015 yang berasal dari SMK Jurusan Akuntansi dan Administrasi Perkantoran dan dari SMAJurusan IPS dan IPA di Program Studi Pendidikan Akuntansi, peneliti dapat mengambil kesimpulan sementara bahwa berdasarkan IP ataupun hasil belajar mahasiswa tersebut lebih 
tinggi mahasiswa yang berasal dari SMK Jurusan Akuntansi dan Administrasi Perkantoran dibanding dari SMA Jurusan IPS dan IPA.

Adapun tujuan dalam penelitian ini adalah untuk mengetahui perbedaan hasil belajar antara mahasiswa yang berasal dari SMA dengan SMK pada Program Studi Pendidikan Akuntansi Universitas PGRI Palembang.

Menurut pengertian secara Psikologi (dalam Slameto, 2010:2) "Belajar merupakan suatu proses perubahan yaitu perubahan tingkah laku sebagai hasil dari interaksi dengan lingkungannya dalam memenuhi kebutuhan hidupnya".

"Hasil belajar adalah kemampuan-kemampuan yang dimiliki siswa setelah ia menerima pengalaman belajarnya" (Sudjana, 2009:22). Menurut Dimyati dan Mudjiono (2013:200) "Hasil belajar merupakan proses untuk menentukan nilai belajar siswa melalui kegiatan penilaian atau pengukuran hasil belajar".

\section{METODOLOGI PENELITIAN}

Peneliti melakukan penelitian diProgram Studi Pendidikan Akuntansi Universitas PGRI Palembang.Penelitian dilakukan dalam jangka waktu kurang dari satu bulan, dengan mengambil nilai dari dosen yang ada di Program Studi Pendidikan Akuntansi dan melakukan penyebaran angket pada dua angkatan yaitu angkatan 2014 dan 2015.

"Metode penelitian adalah cara yang digunakan oleh peneliti dalam mengumpulan data penelitian" (Arikunto, 2013:203). Berdasarkan jenis penelitian yang dilakukan peneliti maka metode yang digunakan adalah metode komparatif.

Berdasarkan pendapat Sugiyono (2014:14) "Metode komparatif adalah suatu penelitian yang bersifat membandingkan keberadaan satu variabel atau lebih pada dua atau lebih sampel yang berbeda".

"Variabel penelitian adalah segala sesuatu yang berbentuk apa saja yang ditetapkan oleh peneliti untuk dipelajari sehingga diperoleh informasi tentang hal tersebut, kemudian ditarik kesimpulannya" (Sugiyono, 2010:2). Sedangkan menurut Arikunto (2013:161) "Variabel penelitan adalah objek penelitian atau apa yang menjadi titik perhatian suatu penelitian".

Berdasarkan pendapat di atas, dapat disimpulkan bahwa variabel penelitian adalah segala sesuatu yang menjadi objek penelitian. Dalam penelitian ini yang menjadi variabel penelitian adalah:

1. Variabel $\left(X_{1}\right)=$ Hasil Belajar Mahasiswa yang berasal dari SMA Jurusan IPS

2. Variabel $\left(X_{2}\right)=$ Hasil Belajar Mahasiswa yang berasal dari SMA Jurusan IPA 
3. Variabel $\left(X_{3}\right)=$ Hasil Belajar Mahasiswa yang berasal dari SMKJurusan Akuntansi

4. Variabel $\left(X_{4}\right) \quad=$ Hasil Belajar Mahasiswa yang berasal dari SMK Jurusan Administrasi Perkantoran

Definisi Operasional Variabel (DOV)

1. Hasil belajar mahasiswa adalah nilai yang diberikan oleh dosen yang didapatkan atau diperoleh mahasiswa setelah mengikuti proses belajar mengajar. Hasil tersebut dapat dilihat dari Kartu Hasil Studi (KHS ) arsip dari dosen.

2. Mahasiswa yang berasal dari SMA adalah mahasiswa yang sudah terdaftar di Universitas PGRI Palembang pada Program Studi Pendidikan Akuntansi angkatan tahun 2014 dan 2015 yang berlatar belakang dari SMA jurusan IPS dan IPA.

3. Mahasiswa yang berasal dari SMK adalah mahasiswa yang sudah terdaftar di Universitas PGRI Palembang pada Program Studi Pendidikan Akuntansi angkatan tahun 2014 dan 2015 yang berlatar belakang dari SMK jurusan Akuntansi dan Administrasi Perkantoran.

Populasi dalam penelitian ini adalah mahasiswa angkatan 2014 dan 2015 yang berasal dari SMA jurusan IPS dan IPA dengan Mahasiswa yang berasal dari SMK jurusan
Akuntansi dan Administrasi Perkantoran

Sampel dalam penelitian ini adalah mahasiswa angkatan 2014 yang berasal dari SMA Jurusan IPS sebanyak 23 orang, Jurusan IPA 8 orang, dan yang berasal dari SMK jurusan Akuntansi 8 orang, Administrasi Perkantoran". angkatan 2015 Jurusan IPS 19, Jurusan IPA 17, Jurusan Akuntansi 14 orang dan Administrasi Perkantoran". Jumlah keseluruhan sampel 81 Orang.

\section{HASIL DAN PEMBAHASAN Hasil Penelitian}

Sekolah Tinggi Keguruan dan Ilmu Pendidikan Persatuan Guru Republik Indonesia (STKIP PGRI ) Palembang yang sekarang namanya telah diganti menjadi Universitas PGRI Palembang terhitung tahun akademik 2000/2001. Sedangkan dahulu STKIP berdiri pada tahun 1983 dengan surat keputusan PD TK. I PGRI Dati I Propinsi Sumatera Selatan No. 46/ SK / PP III PGRI/ IV/ 83, dan No. 342 A/SK/YPLP PGRI tanggal 1 Desember 1983.

Pada tahun akademik 1984/1985 diizinkan untuk menerima mahasiswa baru dengan surat keputusan koordinator kopertis wilayah II No. 035/M. 05. 02/KOP. II/1984. Berdasarkan SK Mendikbud RI No. 065/0/1986 tanggal 5 Februari 1986, jurusan/program studi yang dibuka tahun akademik 1985/1986 dengan status terdaftar yaitu sebagai berikut: 
1. Jurusan Pendidikan Bahasa dan Seni, Program Studi Pendidikan Bahasa Inggris.

2. Jurusan Pendidikan Ilmu Pengetahuan Sosial, Program Studi Pendidikan Sejarah.

3. Jurusan Pendidikan Ilmu Pengetahuan Alam, Program Studi Pendidikan Matematika.

4. Jurusan Ilmu Pendidikan, Program Studi Psikologi Pendidikan dan Bimbingan.

Pada tahun akademik 1986/1987 STKIP PGRI menambah program studi pada jurusan pendidikan Bahasa dan Seni yaitu program studi pendidikan Bahasa dan Sastra Indonesia, yang memperoleh status "TERDAFTAR" berdasarkan SK Mendikbud RI Nomor 0634/0/1989, tanggal 22 september 1986. Pada tahun 1992, STKIP PGRI menambah lagi Program Studi yang terdiri dari:

1. Program Studi Pendidikan Fisika

2. Program Studi Pendidikan Akuntansi.

Kedua Program Studi tersebut memperoleh status "TERDAFTAR" Berdasarkan SK Direktur Jenderal Pendidikan Tinggi Nomor 0375/Dikti/Kep/1992 tanggal 19 Agustus 1992 dengan program D3 tidak diperkenankan untuk menerima mahasiswa baru lagi. Tahun 1998/1999, STKIP PGRI Palembang telah mendapat izin kembali untuk membuka kedua program studi tersebut, jenjang strata I dengan surat Keputusan

Dirjen

Dikti
No.157/Dikti/Kep/1998, tanggal 25 Mei 1998. Diizinkan untuk menerima mahasiswa baru.

Sejak berdiri hingga saat ini telah beberapa kali terjadi pergantian ketua program studi, antara lain:

1. Drs. Adam Soleh (1992-1998)

2. Sri Marti Pramudena, SE, MM (1998-2000)

3. Dra. Hj. Rosdiana, M.Pd (20002005)

4. Erma Yulaini, S.Pd, M.Si (20052008)

5. Muhammad Toyib, M.Pd (20082012)

6. Zahruddin Hodsay, S.Pd, MM (tahun 2012 - Sekarang)

Analisis pembuktian hipotesis perbedaan hasil belajar antara mahasiswa yang berasal dari SMA dengan SMK dilakukan dengan langkah-langkah sebagai berikut:

1. Hipotesis nihil dan hipotesis alternatif

$\mathrm{Ho}_{1}=U_{2}=U_{3}=U_{4}$ : Tidak terdapat perbedaan hasil belajar antara mahasiswa yang berasal dari SMA Jurusan IPS dan IPA dengan mahasiswa yang berasal dari SMK Jurusan Akuntansi dan Administrasi Perkantoran pada Program Studi Pendidikan Akuntansi Universitas PGRI Palembang

Ha $U_{1} \neq U_{2} \neq U_{3} \neq U_{4}$ :

Terdapat perbedaan hasil belajar antara mahasiswa yang berasal dari SMA Jurusan IPS dan IPA dengan mahasiswa yang berasal dari SMK Jurusan Akuntansi dan 
Administrasi Perkantoran pada Program Studi Pendidikan Akuntansi Universitas PGRI Palembang

2. Statistik Uji

Statistik uji yang digunakan adalah uji varians lebih dari dua sampel, dengan rumus:

$$
\begin{aligned}
F_{0}= & \frac{\text { Rata }- \text { rata kuadrat antarsampel }}{\text { Rata }- \text { rata kuadrat dalam sampel }} \\
& =\frac{n \sum\left(\bar{X}_{j}-\bar{X}\right)^{2} / k-1}{\sum \sum\left(X_{i j}-\bar{X}_{j}\right)^{2} / k(n-1)}
\end{aligned}
$$

3. Taraf Kepercayaan

Taraf kepercayaan digunakan $95 \%$ atau $R$ 0,05. Harga $F$ tabel $R$ 0,05 dengan $\mathrm{dk}$ pembilang $\mathrm{m}-1=$ $3-1=2$ dan $\mathrm{dk}$ penyebut $\mathrm{N}-\mathrm{m}=$ $81-3=78$.

4. Kriteria Pengujian

Terima Ho : Bila

$F_{\text {Hitung }} \leq F_{\text {Tabel }} 3,11$ berarti tolak Ha.

Tolak Ho : Bila

$F_{\text {Hitung }}>F_{\text {Tabel }} 3,11$ berarti terima Ha.

Harga $F$ hitung dibandingkan

dengan harga $F_{\text {tabel }}$, dengan $\mathrm{dk}$ pembilang $=\mathrm{m}-1=3-1=2 \mathrm{dan} \mathrm{dk}$ penyebut $=\mathrm{N}-\mathrm{m}=81-3=78$. Berdasarkan dk pembilang $=2$ dan $\mathrm{dk}$ penyebut $=78$, di temukan harga $F_{\text {tabel }}=3,11$ untuk $5 \%$ dan 4,88 untuk $1 \%$ ternyata harga $F_{\text {hitung }}=$ $6,152>F_{\text {tabel }}$ baik untuk $5 \%(3,11)$ maupun untuk $1 \%(4,88)$. Jadi $(6,152$ $>3,11>4,88)$. Dengan demikian Ho ditolak dan $\mathrm{Ha}$ diterima. Kesimpulannya terdapat perbedaan yang sangat signifikan antara hasil belajar mahasiswa yang berasal dari SMA jurusan IPS dan IPA dengan SMK jurusan Akuntansi Pada
Program Studi Pendidikan Akuntansi Universitas PGRI Palembang.

\section{Pembahasan}

Penelitian ini untuk melihat perbedaan hasil belajar antara mahasiswa yang berasal dari SMA Jurusan IPS dan IPA dengan SMK Jurusan Akuntansi Pada Program Studi Pendidikan Akuntansi Universitas PGRI Palembang. Untuk mengumpulkan data hasil belajar mahasiswa, peneliti menggunakan data dokumentasi yang mengambil berkas nilai dari dosen yang melihat data nilai pengantar akuntansi disemester pertama. Selain itu juga peneliti menggunakan data pendukung berupa angket guna melihat asal sekolah dan jurusan mahasiswa waktu di SMA dan SMK.

Dari penelitian ini peneliti mengambil hipotesis yang menyatakan bahwa "Ada perbedaan hasil belajar Mata Kuliah Pengantar Akuntansi antara mahasiswa yang berasal dari SMA Jurusan IPS dan IPA dengan SMK Jurusan Akuntansi Pada Program Studi Pendidikan Akuntansi Universitas PGRI Palembang".Hipotesis ini diambil berdasarkan jumlah jam pelajaran yang diterima mahasiswa dalam menerima pelajaran akuntansi di sekolah yang dilihat dari silabus SMA dan SMKyang mana mahasiswa yang berasal dari SMA Jurusan IPS menerima pelajaran Akuntansi sebanyak 116 jam pelajaran dari jumlah total mata 
pelajaran yang disajikan selama 1tahunajaran. Mata pelajaran akuntansi yang didapat dimulai dari semester 5 dan 6. Mahasiswa yang berasal dari SMA jurusan IPA mendapatkan pelajaran ekonomi sebanyak 62 jam dari jumlah total mata pelajaran yang disajikan selama 4 semester. Sedangkan mahasiswa yang berasal dari SMK jurusan Akuntansi mendapat pelajaran akuntansi sebanyak 39015 menit atau 650 jam pelajaran yang disajikan selama 3 tahun berturut-turut. Mahasiswa yang berasal dari SMK jurusan Administrasi Perkantoran mendapat pelajaran akuntansi sebanyak 56 jam dari jumlah total mata pelajaran yang disajikan selama 3 semester. Mata pelajaran Akuntansi yang didapat dimulai dari semester awal dan hingga sampai semester 3 .

Dalam penelitian ini peneliti menggunakan statistik parametris uji komparatif lebih dari dua sampel independen yang cara perhitungannya adalah kedua sampel yang jurusannya sama angkatan 2014 dan 2015 digabungkan menjadi satu, yaitu mahasiswa yang berasal dari SMA jurusan IPS dan IPA dengan SMK jurusan Akuntansi.

Darihasil penelitian dan pengujian seperti terterah pada halaman $37 \mathrm{~s} / \mathrm{d} \quad 41$ didapat dari $F_{\text {hitung }} \quad$ sebesar $6,152>F_{\text {tabel }}$ berdasarkan dk pembilang $=\mathrm{m}-1=$ $3-1=2$ dan dk penyebut $=\mathrm{N}-\mathrm{m}=$ 81- $3=78$ di temukan harga $F$ tabel
$=3,11$ untuk $5 \%$ dan 4,88 untuk $1 \%$. Jadi $(6,152>3,11>4,88)$, berarti perbedaan hasil belajar antara mahasiswa yang berasal dari SMA dengan SMK pada Program Studi Pendidikan Akuntansi Universitas PGRI Palembang sangat signifikan karena $\quad F_{\text {hitung }}>F_{\text {tabel }}$. Dengan demikian dapat diambil kesimpulannya terdapat perbedaan yang sangat signifikan antara hasil belajar mahasiswa yang berasal dari SMA dengan SMK pada Program Studi Pendidikan Akuntansi Universitas PGRI Palembang. Dengan penelitian ini dinyatakan bahwa Ho ditolak dan Ha diterima.

Berdasarkan tabel bantu hasil perhitungan dengan uji varians lebih dari dua sampel menunjukkan ratarata dari ketiga jurusan IPS, IPA dan Akuntansi menunjukan hasil yang sangatsignifikan, dimana rata-rata IPA 77,16, IPS sebesar 80,595dan Akuntansi 86,429 yang memiliki nilai rata-rata tertinggi adalah mahasiswa yang berasal dari SMK jurusan Akuntansi dan nilai rata-rata terendah adalah mahasiswa yang berasal dari SMA jurusan IPA.

Berdasarkan hasil pengujian diatas, tentang Perbedaan Hasil Belajar Antara Mahasiswa yang Berasal dari SMA dengan SMK pada Program Studi Pendidikan Akuntansi Universitas PGRI Palembang. Menunjukan ada perbedaan yang sangat signifikan. Hal ini berarti menunjukkan latar belakang, dasar pendidikan, jumlah jam pelajaran 
akuntansi dan keahlian keilmuan dalam bidang akuntansi yang diterima di antara mereka berbeda yaitu mahasiswa yang berasal dari SMA jurusan IPS dan IPA dengan Mahasiswa yang berasal dari SMK jurusan Akuntansi, menyebabkan perbedaan yang signifikan diantara tiga golongan tersebut.

Perbedaan hasil belajar mahasiswa dipengaruhi karena dasar pendidikan mereka berbeda-beda yaitu dari SMA jurusan IPS dan IPA dengan SMK jurusan Akuntansi dan Administrasi Perkantoran dalam menerima mata pelajaran akuntansi berbeda sehingga menyebabkan nilai mahasiswa bervariasi.

Dilihat dari data hasil angketyang menunjukan dengan persentase antara mahasiswa angkatan 2014 dan 2015 Prodi Pendidikan Akuntansi mahasiswa dari SMA jurusan IPA dengan persentase $30 \%$, jurusan IPS 52\% dan mahasiswa yang berasal dari SMK jurusan Akuntansi dengan persentase $18 \%$ dan Administrasi Perkantoran $2 \%$ yang berarti mahasiswa terbanyak dari SMA jurusan IPS dan Mahasiswa terendah yang berasal dari SMK jurusan Administrasi Perkantoran.Pada Program Studi Pendidikan Akuntansi mahasiswa yang dominan adalah mahasiswa dari SMA jurusan IPS yang lebih banyak menyukai jurusan Akuntansi.

\section{KESIMPULAN DAN SARAN}

Berdasarkan

hasil

pembahasan, maka dapat diambil suatu kesimpulan sebagai berikut:

1. Berdasarkan hasil penelitian diperoleh rata-rata nilai Pengantar Akuntansi mahasiswa angkatan 2014 dan 2015 yang berasal dari SMA Jurusan IPA 77,16,Jurusan IPS sebesar 80,595, dan mahasiswa yang berasal dari SMK Jurusan Akuntansi sebesar 86,429 , yang memiliki nilai ratarata tertinggi adalah mahasiswa yang berasal dari SMK Jurusan Akuntansi dan nilai rata-rata terendah adalah mahasiswa yang berasal dari SMA Jurusan IPA.

2. Dari hasil pengujian dengan menggunakan statistik parametris uji komperatif lebih dari dua sampel independen. Dari perhitungan didapat dari $F_{\text {hitung }}$ sebesar 6,152 $>F_{\text {tabel }}$ berdasarkan $\mathrm{dk}$ pembilang $=\mathrm{m}-1=3-1=2$ dan dk penyebut $=\mathrm{N}-\mathrm{m}=81-3$ $=78$ di temukan harga $\mathrm{F}$ tabel $=$ 3,11 untuk $5 \%$ dan 4,88 untuk $1 \%$. Jadi $(6,152>3,11>4,88)$, berarti $H_{a}$ diterima dan $H_{o}$ ditolak. Jadi terdapat perbedaan yang sangat signifikan antara hasil belajar mahasiswa yang berasal dari SMA dengan SMK pada Program Studi Pendidikan Akuntansi Universitas PGRI Palembang.

3. Hasil belajar mahasiswa berupa nilai Pengantar Akuntansi antara mahasiswa yang berasal dari 
SMA Jurusan IPS dan IPA dengan mahasiswa yang berasal dari SMK Jurusan Akuntansi memiliki perbedaan nilai yang sangat signifikan sebesar Mahasiswa yang berasal dari SMA jurusan IPA 77,16, jurusan IPS sebesar 80,595dengan selisih sebesar 3,435 dan mahasiswa yang berasal dari SMK jurusan Akuntansi sebesar 86,429 dengan selisih rata-rata antara jurusan IPS 5,834 dan jurusan IPA 9,269.

Berdasarkan kesimpulan di atas maka peneliti memberikan masukan atau saran sebagai berikut:

1. Bagi Program Studi Pendidikan Akuntansi. Diharapkan untuk lebih memperhatikan nilai mahasiswa yang berasal dari SMA jurusan IPA untuk membuat tambahan belajar di luar jam pelajaran tentang materi akuntansi.

2. Bagi Dosen. Agar lebih meningkatkan mutu pendidikan dalam hal ini yaitu meningkatkan prestasi atau hasil belajarr mahasiswa dan lebih memperhatikan gaya belajar mahasiswa terutama mahasiswa yang berasal dari SMA jurusan IPA yang belum pernah mendapatkan pelajaran akuntansi.

3. Bagi Mahasiswa. Agar hendaknya dapat menguasai atau mempelajari setiap pelajaran terutama pelajaran akuntansi agar mendapatkan prestasi yang baik dan diharapkan untuk belajar lagi diluar jam pelajaran kuliah.

4. Bagi Peneliti Lain. Hasil penelitian ini dapat dijadikan sebagai referensi yang relevan dan informasi bagi pihak-pihak yang mempunyai kepentingan terutama penelitian yang sejenis di masa mendatang.

\section{DAFTAR PUSTAKA}

FKIPUniversitas PGRI. 2015. Pedoman Penulisan Skripsi. Palembang: FKIP Universitas PGRI Palembang.

Ahmadi, Uhbiyanti. 2015. Ilmu Pendidikan. Jakarta: Rineka Cipta.

Sudjana, Nana. 2009. Penilaian Hasil Proses Belajar Mengajar. Bandung: PT Remaja Rosdakarya.

Slameto. Belajar dan Faktor-Faktor yang Mempengaruhinya. Jakarta: Rineka Cipta

Sudjana, Nana. 2014.Dasar-Dasar Proses Belajar Mengajar. Bandung: Sinar Baru Algensindo.

Dimyati dan Mudjiono. 2013. Belajar \& Pembelajaran.Jakarta: Rineka Cipta.

Hamalik, Oemar. 2014. Psikologi Belajar Mengajar. Bandung: Percetakan Sinar Baru Algensindo.

Djamarah dan Zain. 2014. Strategi Belajar Mengajar. Jakarta: Rineka Cipta.

Djamarah, Syaiful Bahri. 2010. Guru dan Anak Didik Dalam Interaksi Edukatif. Jakarta: Rineka Cipta. 
Supardi. 2015. Penilaian Autentik. Jakarta: PT Rajagrafindo Persada.

Undang-Undang RI Nomor 9 Tahun 2009. Tentang Badan Hukum Pendidikan. Surabaya : Kesindo Utama.

catatansimade.(http://blogspot.co.id/ 2015/03/pengertian-sekolahmenengah-atas-smasmk.html (diakses tanggal 22 Maret 2016, Pukul 21.00 Wib).

Yusnita, Hetti. 2004. "Perbedaan Indeks Prestasi Komulatif (IPK) Antara Mahasiswa Yang Berasal Dari SMU jurusan IPA Dengan IPS Di Program Studi Pendidikan Ekonomi Akuntansi FKIP Univ. PGRI Palembang. Palembang: FKIP Universitas PGRI Palembang.

Arikunto, Suharsimi. 2013. Prosedur Penelitian Suatu Pendekatan Praktik. Jakarta; Rineka Cipta.

Sugiyono. 2014.Metode Penelitian Bisnis. Bandung: Alfabeta

Sugiyono. 2014. Statistik Untuk Penelitian. Bandung: Alfabeta.

Priyatno, 2010. Paham Analisis Statistik Data dengan SPSS. Yogyakarta: Mediakom.

Supranto, 2009. Statistik Teori dan Aplikasi. Jakarta: Erlangga. 